\title{
Provenance of upper Triassic sandstone, southwest Iberia (Alentejo and Algarve basins): tracing variability in the sources
}

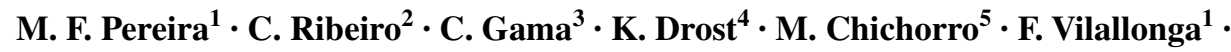 \\ M. Hofmann ${ }^{6}$ U. Linnemann 6
}

Received: 22 March 2015 / Accepted: 31 December 2015

(C) Springer-Verlag Berlin Heidelberg 2016

\begin{abstract}
Laser ablation ICP-MS U-Pb analyses have been conducted on detrital zircon of Upper Triassic sandstone from the Alentejo and Algarve basins in southwest Iberia. The predominance of Neoproterozoic, Devonian, Paleoproterozoic and Carboniferous detrital zircon ages confirms previous studies that indicate the locus of the sediment source of the late Triassic Alentejo Basin in the pre-Mesozoic basement of the South Portuguese and OssaMorena zones. Suitable sources for the Upper Triassic Algarve sandstone are the Upper Devonian-Lower Carboniferous of the South Portuguese Zone (Phyllite-Quartzite and Tercenas formations) and the Meguma Terrane (present-day in Nova Scotia). Spatial variations of the sediment sources of both Upper Triassic basins suggest a more complex history of drainage than previously documented involving other source rocks located outside present-day
\end{abstract}

Electronic supplementary material The online version of this article (doi:10.1007/s00531-016-1295-2) contains supplementary material, which is available to authorized users.

M. F. Pereira

mpereira@uevora.pt

1 Instituto D. Luiz, Departamento de Geociências, ECT, Universidade de Évora, Évora, Portugal

2 Departamento de Geociências, ECT, Universidade de Évora, Évora, Portugal

3 Departamento de Geociências, Instituto de Ciências da Terra de Évora, ECT, Universidade de Évora, Évora, Portugal

4 AG Isotopengeochemie, Eberhard Karls Universität Tübingen, Tübingen, Germany

5 Centro de Investigação em Ciência e Engenharia Geológica, Universidade Nova de Lisboa, Lisbon, Portugal

6 Senckenberg Naturhistorische Sammlungen Dresden, Museum für Mineralogie und Geologie, Dresden, Germany
Iberia. The two Triassic basins were isolated from each other with the detrital transport being controlled by two independent drainage systems. This study is important for the reconstruction of the late Triassic paleogeography in a place where, later, the opening of the Central Atlantic Ocean took place separating Europe from North America.

Keywords U-Pb zircon geochronology · Provenance analysis $\cdot$ Upper Triassic basins $\cdot$ Pangaea

\section{Introduction}

Detrital zircon geochronology is a commonly used tool for provenance studies because of the widespread occurrence of zircon in sedimentary systems and the growing ability to determine ages with reasonable precision, accuracy, and efficiency (Corfu et al. 2003; Fedo et al. 2003; von Eynatten and Dunkl 2012). The U-Pb age of a detrital zircon grain provides a proxy for the age of the source rock in which the zircon originally formed (Sircombe and Hazelton 2004). In provenance studies of ancient basins, it is critical to consider tectonics, exhumation processes, erosion and sedimentary recycling because availability of zircon to erosion and transport from either primary crystalline or recycled sources requires that the zircon-bearing rocks be exposed at the appropriate time, and recycling from older sedimentary deposits may constitute a more significant source than from primary crystalline rocks (Thomas 2011).

During Permian to Triassic time, the paleogeography of Iberia was dominated by a series of coalescing, alluvial-deltaic wedges and axial braided rivers that filled continental rift basins (Palain 1976; Wilson 1988; Arche and López-Gómez 1996; López-Gómez et al. 2005; Sánchez Martínez et al. 2012; Soares et al. 2012). In Portugal, Permian-Triassic 